\title{
Plasminogen activator inhibitor 1 (PAI-1) 1334G/A genetic polymorphism in colorectal cancer ${ }^{*}$
}

\author{
Beata Smolarz ${ }^{\bowtie}$, Hanna Romanowicz-Makowska and Andrzej Kulig \\ Laboratory of Molecular Genetics, Department of Pathology, Institute of Polish Mother's \\ Memorial Hospital, Łódż, Poland
}

Received: 22 April, 2002; revised: 22 April, 2003; accepted: 19 May, 2003

Key words: plasminogen activator inhibitor 1 (PAI-1), 1334G/A polymorphism, colorectal cancer, prognostic marker, PCR

\begin{abstract}
Plasminogen activator inhibitor 1 (PAI-1) content in colorectal cancer tissue extracts may be of strong prognostic value: high levels of PAI-1 in tumours predict poor prognosis. The gene encoding PAI-1 is highly polymorphic and PAI-1 gene variability could contribute to the level of PAI-1 biosynthesis. In the present work the distribution of genotypes and frequency of alleles of the 1334G/A polymorphism in 92 subjects with colorectal cancer in samples of cancer tissue and distant mucosa samples as well as in blood were investigated. Blood samples age matched healthy individuals (n = 110) served as control. The 1334G/A polymorphism was determined by PCR amplification using allele specific primers. No differences in the genotype distributions and allele frequencies between blood, distant mucosa samples and cancer tissue were detected. However, the distribution of the genotypes of the $1334 \mathrm{G} / \mathrm{A}$ polymorphism in patients differed significantly $(P<0.05)$ from those predicted by the Hardy-Weinberg equilibrium. There were significant differences in the frequencies of alleles between the colorectal cancer subjects and controls $(P<0.05)$. The results support the hypothesis that the 1334G/A polymorphism may be associated with the incidence of colorectal cancer.
\end{abstract}

Invasion and metastasis of malignant tumours require proteolytic degradation of the extracellular matrix (ECM) and the basement membrane and infiltration of tumour cells into the surrounding tissue, the blood stream, and/or the lymphatic vessels (Meyer \& Hart, 1998). At least four different types of tumour-associated proteases may be responsi-

\footnotetext{
${ }^{\star}$ This work was supported by grant 4P05B01317 from the State Committee for Scientific Research (KBN, Poland).

${ }^{\bowtie}$ Please send all correspondence to Beata Smolarz, Laboratory of Molecular Genetics, Department of Pathology, Institute of Polish Mother's Memorial Hospital, Rzgowska 281/289, 93-338 Łódź, Poland; phone: (48 42) 271 1280; fax: (48 42) 271 1421, e-mail: smolbea@wp.pl
}

Abbreviations: PAI-1, plasminogen activator inhibitor 1; ECM, extracellular matrix; uPA, urokinase type plasminogen activator; uPAR, urokinase receptor. 
ble for degradation of the tumour stroma and tumour cell invasion: cysteine proteases, aspartate proteases, matrix metalloproteases and serine proteases (Dano et al., 1999). The components of the plasminogen activation system: urokinase type plasminogen activator (uPA), the specific plasminogen activator inhibitors PAI-1 and PAI-2 and the urokinase receptor (UPAR), released by cancer cells, stimulate tumour invasion (Carroll \& Binder, 1999). High levels of uPA, uPAR and PAI-1 are associated with poor prognosis in a variety of cancers (Lijnen, 2001; Schmitt et al., 1997).

Patients with colorectal cancer can be cured by surgical treatment only if the cancer is detected at an early stage of the disease (Weiss \& Itzkowitz, 1995). It is therefore important to identify high-risk and low-risk patients by suitable markers.

Many studies have shown that PAI-1 may be a useful prognostic marker in colorectal cancer (Abe et al., 1999; Fuji et al., 1999; Herszenyi et al., 1999; Sattar \& McMillan, 1998; Nielsen et al., 1998). An elevated level of PAI-1 can be associated with shorter recurrence-free survival and shorter overall survival. Changes in PAI-1 biosynthesis are usually preceded by changes in its gene transcription and mRNA level (Henry et al., 1998). Gene variability could contribute to the level of PAI-1 biosynthesis. Ten different polymorphisms within the PAI-1 gene have been described: an $\mathrm{A} \rightarrow \mathrm{G}$ substitution in position +1334 in the propeptide coding region, two $(\mathrm{CA})_{\mathrm{n}}$ repeat polymorphisms, one in the promoter and one in intron 4; a HindIII restriction fragment length polymorphism; an insertion (5G)/deletion (4G) polymorphism at position -675 of the promoter; two $\mathrm{G} \rightarrow$ A substitutions at positions -844 , and +9785 ; three polymorphisms in the 3 ' untranslated region: a $\mathrm{T} \rightarrow \mathrm{G}$ substitution at position +11053 and a 9-nucleotide insertion/deletion located between nucleotides +11320 and +11345 in a thrice repeated sequence, and a $\mathrm{G} \rightarrow \mathrm{A}$ substitution in position +12078 (Henry et al., 1997; Mansfield et al., 1995; Falk et al., 1999).
In light of the substantial evidence that the progression of colorectal cancer can be associated with elevated level of PAI-1, it seems reasonable to check the possible correlation between these polymorphisms and/or progression of this cancer.

Among the polymorphic variants of the PAI-1 gene an insertion (5G)/deletion (4G) polymorphism (4G/5G polymorphism) was most frequently studied. It is associated with high plasma PAI-1 levels in patients with coronary artery disease (Grancha et al., 1999; Stegnar et al., 1998), myocardial infarction (Eriksson et al., 1995; Ye et al., 1995) and diabetes (Mansfield et al., 1995; Burzotta et al., 1998). The role of the $4 \mathrm{G} / 5 \mathrm{G}$ polymorphism was investigated also in subjects with breast (Smolarz \& Błasiak, 1999; 2000), endometrial (Błasiak et al., 2000) and colorectal cancer (Smolarz et al., 2001; Błasiak et al., 2000) but a lack of association between this sequence variation and cancer progression was observed.

In the present work the relationship between the $1334 \mathrm{G} / \mathrm{A}$ polymorphism in the propeptide coding region of the PAI- 1 molecule and the appearance and/or invasiveness of colorectal cancer was examined. It was reported earlier that particular genotypes of the $1334 \mathrm{G} / \mathrm{A}$ polymorphism could be associated with bleeding tendency (Falk et al., 1999), but little is known on possible role of this polymorphism in cancer.

In our study the distribution of genotypes and the frequency of alleles of the 1334G/A polymorphism in subjects with colorectal cancer were investigated.

\section{MATERIALS AND METHODS}

Patients. Tumour tissues, distant mucosa samples and blood were obtained from $92 \mathrm{sub}$ jects with colorectal cancer treated at the $2 \mathrm{nd}$ Department of Surgery, Military Academy of Medicine in Łódź (Poland) between 1998 and 2001. Clinical data for the patients and histo- 
logical data were registered. There were 56 males and 36 females and their mean age was 59 years (range: 37-71 years). All tumours were graded according to Dukes's stages. There were 25 tumours of A stage, 40 of B stage and 27 of $\mathrm{C}$ stage in total. Blood samples from age matched healthy individuals $(\mathrm{n}=$ 110) served as control.

Determination of the 1334 G/A polymorphism. DNA was extracted using commercially available QIAmp Kit (Qiagen $\mathrm{GmbH}$, Hilden, Germany) DNA purification kit according to manufacturer's instruction. Genotypes of the $1334 \mathrm{G} / \mathrm{A}$ polymorphism were determined by polymerase chain reaction amplification of genomic DNA using the following allele specific primers: two 17-mer: $5^{\prime}-\mathrm{TCA}$ CCA AAG ACA AGG GC-3', and 5' - TCA CCA AAG ACA AGG GT-3' in combination with an upstream primer, 5' -TGT TCA CTT ACC ACC TGC TT-3' (Falk et al., 1999). The amplification results in a DNA fragment of $182 \mathrm{bp}$ and was performed in a total volume of $25 \mu \mathrm{l}$. The PCR was carried out in a DNA Thermal Cycler (GeneAmp PCR System 2400; Perkin-Elmer, Norwalk, CT, U.S.A.). The thermal cycling conditions were $30 \mathrm{~s}$ at $94^{\circ} \mathrm{C}, 30 \mathrm{~s}$ at $60^{\circ} \mathrm{C}, 30 \mathrm{~s}$ at $72^{\circ} \mathrm{C}$, repeated for 30 cycles. The reaction mixture contained $1 \mu \mathrm{g}$ of genomic DNA, $0.2 \mu \mathrm{mol}$ of each appropriate primer (ARK Scientific GmbH Biosystems, Darmstad, Germany), $2.5 \mathrm{mM} \mathrm{MgCl}_{2}, 1 \mathrm{mM}$ dNTPs (Qiagen GmbH, Hilden, Germany) and 1 unit of Taq Polymerase (Qiagen). PCR products were electrophoresed in a 5\% polyacrylamide gel (PAGE) and visualised by ethidium bromide staining. Each subject was classified into one of the three possible genotypes: $G / G$, G/A or A/A.

Statistical analysis. The allelic frequencies were estimated by gene counting and the genotypes were scored. The observed numbers of each PAI-1 genotype were compared with those expected for a population in HardyWeinberg equilibrium by using the $\chi^{2}$ test. The significance of the differences of the ob- served allele and genotype frequencies between groups was tested using the $\chi^{2}$ analysis.

\section{RESULTS}

From the PCR analysis, all patients and controls were classified into three genotypes of the 1334G/A polymorphism: G/G, G/A and A/A (Fig. 1). There were no differences in the frequencies of the $\mathrm{A}(0.28)$ and $\mathrm{G}(0.72)$ alleles between blood, normal and cancer tissue in the patients.

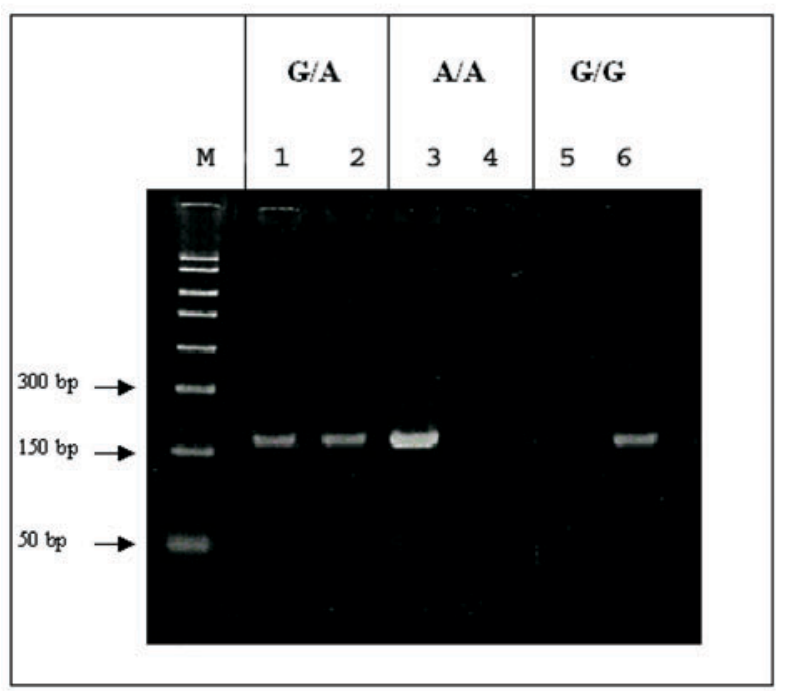

Figure 1. A typical result of allele specific polymerase chain reaction performed with a fragment of the promoter of PAI-1 gene and analysed by 5\% polyacrylamide gel electrophoresis, staining with ethidium bromide and viewed under ultraviolet light.

Lanes 1, 3 and 5 display the product of amplification with the primer pair specific for the A allele; lanes 2, 4 and 6, the $\mathrm{G}$ allele; M, molecular mass markers, 50-2000 bp (Sigma, St. Louis, U.S.A.).

The distributions of the G/A genotypes as well as the frequencies of the $A$ and $G$ alleles for colorectal cancer patients and control are shown in Table 1. It can be seen from the Table that there were significant differences $(P<$ 0.05 ) between the two investigated groups. The frequencies of the $\mathrm{A}$ and $\mathrm{G}$ alleles were 
Table 1. Distribution of G/G, G/A and A/A genotypes and frequencies of the G and A alleles in patients with colorectal cancer and controls

\begin{tabular}{|c|c|c|c|c|}
\hline & \multicolumn{2}{|c|}{ Patients $(\mathrm{n}=92)$} & \multicolumn{2}{|c|}{ Controls $(n=110)$} \\
\hline & Number & Frequency & Number & Frequency \\
\hline A/A genotype & 16 & 0.17 & 26 & 0.24 \\
\hline $\mathrm{G} /$ A genotype & 19 & 0.21 & 52 & 0.47 \\
\hline G/G genotype & 57 & 0.62 & 32 & 0.29 \\
\hline$\chi^{2}$ & \multicolumn{2}{|c|}{$23.644^{\mathrm{a}}$} & \multicolumn{2}{|c|}{$0.309^{a}$} \\
\hline A allele & 51 & $0.28^{\mathrm{b}}$ & 104 & 0.47 \\
\hline $\mathrm{G}$ allele & 133 & $0.72^{\mathrm{b}}$ & 116 & 0.53 \\
\hline
\end{tabular}

${ }^{\mathrm{a}} P<0.05$ as compared with Hardy-Weinberg distribution; ${ }^{\mathrm{b}} P<0.05$ as compared with the controls.

0.28/0.72 in patients and $0.47 / 0.53$ in controls. In patients the observed frequencies of the G/G, G/A and A/A genotypes differed significantly $(P<0.05)$ from the distribution expected from the Hardy-Weinberg equilibrium.

The dependencies of the distribution of genotypes and frequencies of alleles on the tumour stage evaluated according to Dukes criteria of patients with colorectal cancer are displayed in Table 2. There were no significant differences between the distributions of genotypes in the subgroups assigned to the histological stage and the distribution pre- dicted by Hardy-Weinberg equilibrium $(P>$ 0.05). There were no differences in the frequencies of the $\mathrm{A}$ and $\mathrm{G}$ alleles between the subgroups either $(P>0.05)$.

\section{DISCUSSION}

Genetic factors have been shown to influence protein level for several haemostatic factors (Błasiak et al., 2000). The 1334G/A polymorphism of the PAI-1 gene has been associated with interindividual differences in the

Table 2. Dependency of A/A, G/A and G/G genotypes and frequencies of the A and G alleles on tumour stage in patients with colorectal cancer ${ }^{\mathrm{a}}$

\begin{tabular}{lcccccc}
\hline Stage $^{\mathrm{b}}$ & \multicolumn{2}{c}{$\mathrm{A}(\mathrm{n}=25)$} & \multicolumn{2}{c}{$\mathrm{B}(\mathrm{n}=40)$} & \multicolumn{2}{c}{$\mathrm{C}(\mathrm{n}=27)$} \\
\hline & Number & Frequency & Number & Frequency & Number & Frequency \\
A/A genotype & 7 & 0.28 & 7 & 0.18 & 7 & 0.26 \\
G/A genotype & 11 & 0.44 & 20 & 0.50 & 11 & 0.41 \\
G/G genotype & 7 & 0.28 & 13 & 0.32 & 9 & 0.33 \\
$\chi^{2}$ & \multicolumn{2}{c}{$0.360^{\mathrm{C}}$} & & $0.028^{\mathrm{c}}$ & \multicolumn{2}{c}{$0.886^{\mathrm{c}}$} \\
A allele & 25 & 0.50 & 34 & 0.43 & 25 & 0.46 \\
G allele & 25 & 0.50 & 46 & 0.57 & 29 & 0.54 \\
\hline
\end{tabular}

${ }_{\mathrm{n}}^{\mathrm{a}}=92 ;{ }^{\mathrm{b}}$ according to Dukes criteria; ${ }^{\mathrm{c}} \mathrm{P}>0.05$ as compared with Hardy-Weinberg distribution. 
basal steady state level of its protein (Falk et $a l ., 1999)$. In addition, responses to environmental factors have been shown to differ by genotype (Green \& Humphries, 1994).

Little is known about the possible role of the PAI-1 gene polymorphisms in cancer. In our earlier studies we showed that the $4 \mathrm{G} / 5 \mathrm{G}$ polymorphism and $\mathrm{G} \rightarrow \mathrm{A}$ substitutions at position -844 (G/A polymorphism) of PAI-1 are not linked with the appearance of colorectal cancer (Smolarz et al., 2001; Błasiak et al., 2000). In the present study we show that there is association between the genotypes of the 1334G/A polymorphism in the propeptide coding region of $P A I-1$ and the incidence of colorectal cancer in a group of 92 patients.

In an analysis of the exons of the PAI-1 gene only one base change was identified at base pair number 1334 (numbering according to Bosma et al., 1988) where both $\mathrm{G}$ and A were present. The base change (G1334 $\rightarrow$ A) causes a change of alanine at residue -9 in the propeptide of the PAI-1 molecule to threonine.

The 1334G/A polymorphism was found to be associated with severe bleeding problems, similar to those seen in patients with haemophilia (Falk et al., 1999), but no data are available on the association or lack of such association in colorectal cancer. In view of the potentially significant role of PAI-1 for tumour spreading, it is important to know whether this polymorphism can account for the appearance and/or development of colorectal cancer.

It should be also taken into account that in addition to the genotype also environmental factors affect plasma PAI-1 levels. PAI-1 synthesis has been related to high blood levels of glucose, insulin and triglycerides (Eriksson et al., 1995), sex hormones (Yang et al., 1993) and angiotensin IV (Kerins et al., 1995). Increased level of PAI-1 can be also linked with smoking habits (Eliasson et al., 1994), alcohol consumption (Hendriks et al., 1994) and acute infections (Pralong et al., 1989).

In the present work a PCR method was used to screen 92 colon cancer patients for the
1334G/A polymorphism. We detected a significant difference in distribution frequency of alleles between patients and control $(P<$ $0.05)$. The distribution of the genotypes in the patients differed from one expected from the Hardy-Weinberg equilibrium, with an overrepresentation of $\mathrm{G} / \mathrm{G}$ homozygotes. It is possible that the presence of the $G$ allele is in linkage disequilibrium with another, so far unknown, mutation located outside the coding region in the PAI-1 gene, which may be of importance for the PAI-1 concentration in plasma.

On the other hand we did not detect any significant difference between the genotypes in subgroups assigned to histological stages, which suggests a lack of association between the polymorphism and colorectal cancer invasiveness. Moreover, we did not detect any significant difference between the genotypes in blood, distant mucosa samples and cancer tissue.

Our study implies that the $1334 \mathrm{G} / \mathrm{A}$ polymorphism of PAI-1 gene may be associated with the occurrence of colorectal cancer. Further studies, conducted on a larger group, are required to clarify this point.

The authors thank Dr. J. Ulańska of the 2nd Department of Surgery, Military Academy of Medicine in Eódź for providing the colorectal cancer tissue samples. Technical assistance of E. Kozłowska is appreciated.

\section{R E F E R E N C E S}

Abe J, Urano T, Konno H, Erhan Y, Tanaka T, Nishino N, Tahada A, Nakamura S. (1999) Larger and more invasive colorectal carcinoma contains larger amounts of plasminogen activator inhibitor type 1 and its relative ratio over urokinase receptor correlates well with tumor size. Cancer.; 86: 2602-11.

Błasiak J, Smolarz B. (2000) Plasminogen activator inhibitor 1 (PAI-1) gene $4 \mathrm{G} / 5 \mathrm{G}$ promoter polymorphism is not associated with 
breast cancer. Acta Biochim Polon.; 47: 191-9.

Błasiak J, Smolarz B, Kubryn I, Kulig A, Dziki A, Ulańska J, Pander B. (2000) Plasminogen activator inhibitor-1 (PAI-1) level and 4G/5G genetic polymorphism in patients with colorectal cancer. Exp Oncol.; 22: 48-51.

Błasiak J, Smolarz B, Romanowicz-Makowska H, Pertyński T. (2000) Polymorphisms of the promoter region of the plasminogen activator-1 (PAI-1) gene in women with endometrial cancer. Pol J Gynaecol Invest.; 3: 61-6.

Bosma PJ, van den Berg EA, Kooistra T, Siemieniak DR, Slightom JL. (1988) Human plasminogen activator inhibitor 1 gene promoter and structural gene nucleotide sequences. J Biol Chem.; 263: 9129-41.

Burzotta F, Di Castelnuovo A, Amore C, D’Orazio A, Di Bitondo R, Donati MB, Iacoviello L. (1998) 4G/5G promoter PAI-1 gene polymorphism is associated with plasmatic PAI-1 activity in Italians: a model of gene-enviroment interaction. Thromb Haemost.; 79: 354-8.

Carroll VA, Binder BR. (1999) The role of the plasminogen activation system in cancer. Seminars Thromb Haemost.; 25: 183-97.

Dano K, Romer J, Nielsen BS, Bjorn S, Pyke C, Rygaard J, Lund R. (1999) Cancer invasion and tissue remodeling - cooperation of protease systems and cell types. APMIS.; 107: 120-7.

Eliasson B, Attval S, Taskinen MR, Smith U. (1994) The insulin resistance syndrome in smokers is related to smoking habits. Arterioscler Thromb.; 14: 1446-50.

Eriksson P, Kallin B, van Hooft FM, Bavenholm P, Hamsten A. (1995) Allele-specific increase in basal transcription of the plasminogen activator inhibitor 1 gene is associated with myocardial infarction. Proc Natl Acad Sci $U S$ A.; 92: 1851-5.

Eriksson P, Kallin B, Van't Hooft FM, Bavenholm P, Hamsten A. (1995) Allele-specific increase in basal transcription of the plasminogen-activator inhibitor 1 gene is associated with myocardial infarction. Proc Natl Acad Sci U S A.; 92: 1851-5.

Falk G, Sui GC, Schulman S, Wiman B. (1999) Detection of a new polymorphism in the PAI-1 gene located in the pro-peptide coding region. Fibrinolysis Proteolysis.; 13: 26-30.

Fuji T, Obara T, Tanno S, Ura H, Kohgo Y. (1999) Urokinase type plasminogen activator and plasminogen activator inhibitor 1 as a prognostic factor in human colorectal carcinomas. Hepatogastroenterology.; 28: 2299-308.

Grancha S, Estelles A, Tormo G, Gilabert J, Espana F, Cano A, Segui R, Aznar J. (1999) Plasminogen activator inhibitor-1 (PAI-1) promoter 4G/5G genotype and increased PAI-1 circulating levels in postmenopausal women with coronary artery disease. Thromb Haemost.; 81: 516-21.

Green F, Humphries SE. (1994) Genetic determinants of arterial thrombosis. Balliers Clin Haematol.; 7: 675-93.

Hendriks HFJ, Veenstgra J, Velthuiste Wierik EJM Schaafsma G, Kluft C. (1994) Effect of moderate dose of alcohol with evening meal on fibrinolytic factors. $\mathrm{Br} M e d$ J.; 308: 1003-5.

Henry M, Chomiki N, Scarabin PY, Alessi MC, Peiretti F, Arveiler D, Ferrieres J, Evans A, Amouyel P, Poirier O, Cambien F, Juhan-Vague I. (1997) Five frequent polymorphisms of the PAI-1 gene. Arterioscler Thromb Vasc Biol.; 17: 851-8.

Henry M, Tregoue DA, Alessi MC, Ailland MF, Visvikis S, Siest G, Tiret L, Juhan-Vague I. (1998) Metabolic determinants are much more important than genetic polymorphisms in determining the PAI-1 activity and antigen plasma concetrations: a family study with part of the Stanislas Cohort. Arterioscler Thromb Vasc Biol.; 18: 84-91.

Herszenyi C, Plebani M, Carrano P, De Paoli M, Roveroni G, Cardin R, Tulessay Z, Naccarato R, Forinati F. (1999) The role of cysteine and serine proteases in colorectal carcinoma.

Cancer:; 86: 1135-42. 
Kerins DM, Hao Q, Vaughan DE. (1995) Angiotensin induction of PAI-1 in endothelial cells is mediated by the hexapeptide angiotensin IV. J Clin Invest.; 96: 2515-20.

Lijnen HR. (2001) Elements of the fibrinolytic system. Ann N Y Acad Sci U S A.; 936: $226-36$.

Mansfield MW, Stickland MH, Grant PJ. (1995) Plasminogen activator inhibitor-1. (PAI-1) promoter polymorphism and coronary artery disease in non-insulin dependent diabetes. Thromb Haemost.; 74: 1032-4.

Meyer T, Hart IR. (1998) Mechanisms of tumour metastasis. Eur J Cancer.; 34: 214-21.

Nielsen HJ, Pappot H, Christensen IJ, Brunner N, Thorlacius-Ussing O, Moesgaard F, Dano K, Grondahl-Hansen J. (1998) Association between plasma concetrations of plasminogen activator inhibitor 1 and survival in patients with colorectal cancer. Br Med J.; 316: 829-30.

Pralong G, Calandra T, Glauser MP, Schellekens J, Verhoef J, Bachmann F, Kruithof EKO. (1989) Plasminogen activator inhibitor 1: a new prognostic marker in septic shock. Thromb Haemost.; 61: 459-62.

Sattar N, McMillan DC. (1998) Association between plasma plasminogen activator inhibitor 1 and survival in colorectal cancer measuring $\mathrm{C}$ reactive protein concetrations may be more useful. British Medical J.; 317: $750-1$.

Schmitt M, Harbeck N, Thomssen C, Wilhelm O, Magdolen V, Reuning U, Ulm K, Hofler H, Janicke F, Graeff H. (1997) Clinical impact of the plasminogen activation system in tumor invasion and metastasis: prognostic rele- vance and target for therapy. Thromb Haemost.; 78: 285-96.

Smolarz B, Błasiak J. (1999) Plasminogen activator inhibitor-1 promoter 4G/5G genotype in subjects with breast cancer. Biom Lett.; 60: $97-105$.

Smolarz B, Błasiak J, Kulig A, Romanowicz-Makowska H, Dziki A, Ulańska J, Pander B, Szewczyk T. (2001) Plasminogen activator inhibitor 1 (PAI-1) levels and gene promoter polymorphism in subjects with colorectal cancer. J Exp Clin Cancer Res.; 20: 247-52.

Stegnar M, Uhrin P, Peternel P, Mavri A, Salobir-Pajnic B, Stare J, Binder BR. (1998) The 4G/5G sequence polymorphism in the promoter of plasminogen activator inhibitor-1 (PAI-1) gene: relationship to plasma PAI-1 level in venous thromboembolism. Thromb Haemost.; 79: 975-9.

Weiss AA, Itzkowitz SH. (1995) Biology diagnosis and therapy. In Gastrointestinal Cancers. pp 353-65. Lippincott-Raven, Philadelphia.

Yang XC, Jing TY, Resnick LM, Phillips GB. (1993) Relation of hemostatic risk factors to other risk factors for coronary heart disease and to sex hormone in men. Arterioscler Thromb.; 13: 467-71.

Ye S, Green FR, Scarabin PY, Nicaud V, Bara L, Dawson SJ, Humphries SE, Evans A, Luc G, Cambau JP, Arveiler D, Henney AM,

Cambien F. (1995) The 4G/5G genetic polymorphism in the promoter of the plasminogen activator inhibitor-1 (PAI-1) gene is associated with difference in plasma PAI-1 activity but not risk factor of myocardial infarction in the ECTIM study. Thromb Haemost.; 74: 837-41. 